International Journal of Agriculture, Environment and Bioresearch

Vol. 5, No. 03; 2020

ISSN: $2456-8643$

\title{
BLOOD PROFILES, CEACA MICRO FLORA AND INTESTINAL MORPHOMETRIC OF BROILER CHICKENS FED DIETS SUPPLEMENTED WITH (Syzygium aromaticum, Piper nigrum and Tetrapleura tetraptera) AS ANTIOXIDANTS
}

\author{
Wasiu A. Olayemi ${ }^{1 *}$, Olawale P. Olatidoye ${ }^{2}$; Augustine A. Alade ${ }^{3}$ and Esther A. Shorinola ${ }^{1}$ \\ ${ }^{1}$ Department of Agricultural Technology, Yaba College of Technology, P.M.B 2011,Yaba, Nigeria \\ ${ }^{2}$ Department of Food technology, Yaba College of Technology, P.M.B 2011, Yaba, Nigeria \\ ${ }^{3}$ Africa Centre of Excellence in Agricultural Development and Sustainable Environment, Federal University of \\ Agriculture, Abeokuta, Ogun State, Nigeria \\ https://doi.org/10.35410/IJAEB.2020.5507
}

\begin{abstract}
250 unsexed day old broiler (Cobb) chicks were used to evaluate effects of phytogenic spices on blood profile, intestinal morphometric and gut microflora status. The study consist of five treatments namely: T1-control T2-synthetic antioxidant, T3 -T5 (Syzygium aromaticum, Piper nigrum, Tetrapleura tetraptera at $1 \%$ inclusion and replicated five times in a completely randomized design. Obtained results showed a significant $(\mathrm{P}<0.005)$ effect of phytogenic spices on haematological parameters with an increase in the value (37\%) of PCV in birds fed synthetic antioxidants while lowest value (31\%) was recorded in T1.The broiler chickens on synthetic antioxidants had highest serum protein $(15.37 \mathrm{~g} / \mathrm{l})$ as against $(9.17-9.50 \mathrm{~g} / \mathrm{l})$ in birds (T3-T5). Uric acid, creatinine, globulin, cholesterol values are normal while creatinine values $(1.7-2.5 \mathrm{mg} / \mathrm{dl})$ reflects better protein utilization as confirmed by decreased uric acid values $(0.81-1.74 \mathrm{mg} / \mathrm{dl})$. The active ingredients in the phytogenic plants reduced the Clostridium, Staphylococcus, Salmonella, Coliform, coliform counts in the ceacal contents while Lactobacillus and Bacillus population increased as recorded inT4. Increased villi height/crypt depth ratio $(20 \mu \mathrm{m})$ indicates improved intestinal health as well as increased digestive capacity of the small intestine in broilers fed T. tetraptera. The results trend showed that the present study is constituents dependent with optimal response with $\mathrm{T}$. tetraptera meaning that these phytogenic antioxidants are able to replace the synthetic antioxidant under common feeding practice without any deleterious effect on intestine morphometric, blood profile and caecal microbial in broiler chickens.
\end{abstract}

Keywords: Blood profiles, ceaca flora, intestinal morphometric, antioxidants.

\section{INTRODUCTION}

The emerging interest in natural antioxidants as feed additive could be linked to its health benefits to poultry as well as inhibitory effect on lipid oxidation in poultry meat. The presence of phenolic compounds in herbs and spices (cloves, peppermint, and nutmeg) provide good alternative to synthetic antioxidants (Botsoglou et al. 2013) which assist in the scavenging radicals from rich phytochemical constituents. 
Vol. 5, No. 03; 2020

ISSN: $2456-8643$

Syzygium aromaticum (Clove buds)from the family Myrtaceae have been considered as home remedy for toothaches, joint pains, indigestion, asthma, cough, skin disorders, headache etc.It is used in medicine for its antibiotic properties. However, sesquiterpenes in clove are potential anticarcinogenic agents (Zheng et al., 1992) in addition, the cloves are antioxidant (Chaieb et al., 2007). Its oil as reported by (Khathir et al., 2014) has the highest antioxidant activity comparable to synthetic antioxidants with ability to inhibit $97.3 \%$ lipid peroxidation of linoleic acid emulsion at $15 \mu \mathrm{g} / \mathrm{mL}$ concentration.

Piper nigrumL from Piperaceae family. Its root and fruit are used in palsy, gout and lumbago. The fruits have a bitter, hot, sharp taste, tonic to the liver, aphrodisiac and digestive stimulants (Sashidhar, 2002). Its constituents such as alkaloids, steroids, tannins, phenol compounds, flavonoids, steroids, resins, and fatty acids are capable of producing definite physiological action on disease causing organisms.

Tetrapleura tetraptera belongs to the family mimosaceae. The pods of this plants have appealing culinary use as spices. It has appreciable quantities of phenols, flavonoids, saponins, tannins, steroids and alkaloids which are potential antioxidative agents against liver tumours, toxins, viruses and other microorganisms, allergies and inflammation (Nwoba, 2015).The dry powdered has been formulated into soaps to increase its antimicrobial activity and foaming properties of the soap. It is also used as fish poison and as an ointment on the skin (Adebayo et al., 2000). The focus of this study is to determine the effects of dietary inclusion of Syzygium aromaticum, Piper nigrum and Tetrapleura tetraptera on gut morphometric and micro-flora, Serum indices and haematological parameters of broiler chickens.

\section{MATERIALS AND METHODS}

Experimental site: The experiment was carried out at the Teaching and Research Farm of Yaba College of Technology, Epe, Nigeria. The farm is situated along Epe- Ijebu Ode road on latitude $6.58^{\circ} \mathrm{N}$, Longitude $3.98^{\circ} \mathrm{E}$. It lies in the low land rain forest vegetation zone within the savannah agro ecological zones with altitude at $42 \mathrm{~m}$ above the sea level. The average rainfall of $1694 \mathrm{~mm}$ and temperature of $27.1^{\circ} \mathrm{C}$ exist during the experimental period (Google Earth, 2019).

Preparation of the test Ingredients: The test ingredients; Syzygium aromaticum, Piper nigrum and Tetrapleura tetraptera were purchased from Agege market, Lagos state, Nigeria. They were sun dried to $10-12 \%$ moisture and milled using Kenwood blender with $0.2 \mathrm{~mm}$ sieve. The milled test ingredients were stored in plastic bags for the analysis.

Experimental birds' management and design: Two hundred and fifty-day old unsexed broiler (Cobb) chicks were obtained from a reputable commercial hatchery for this study.The brooding was done under a deep litter system, the chicks were allotted to five dietary treatments (T1-T5) and replicated five times with 10 birds per replicate in a complete randomized design (CRD). Feed and water were offered ad libitum while appropriate vaccination and medication were administered. The test ingredients; Syzygium aromaticum, Piper nigrum and Tetrapleura tetraptera were added to the feed at $1 \%$. Feed was formulated based on Nutrient requirement of broiler (NRC, 1994). T1 - without antioxidants; T2 - with synthetic antioxidants; T3 - with Syzygium aromaticum (Cloves). T4 - with Piper nigrum (Black pepper). T5 - with Tetrapleura tetraptera (Prekese). 
Table 1: Ingredient and chemical composition of basal diet for starter (1-28 D) broiler.

\begin{tabular}{|llrlrr|}
\hline Ingredients & T1 & T2 & T3 & \multicolumn{1}{c|}{ T4 } & T5 \\
\hline Maize & 54.00 & 54.00 & 54.00 & 54.00 & 54.00 \\
Soya bean meal & 30.00 & 30.00 & 30.00 & 30.00 & 30.00 \\
Vegetable oil & 1.00 & 1.00 & 1.00 & 1.00 & 1.00 \\
Wheat offal & 6.00 & 6.00 & 5.00 & 5.00 & 5.00 \\
Fishmeal & 3.00 & 3.00 & 3.00 & 3.00 & 3.00 \\
Bone meal & 3.00 & 3.00 & 3.00 & 3.00 & 3.00 \\
Limestone & 2.00 & 2.00 & 2.00 & 2.00 & 2.00 \\
Salt & 0.25 & 0.25 & 0.25 & 0.25 & 0.25 \\
*Premix & 0.30 & 0.30 & 0.30 & 0.30 & 0.30 \\
Methionine & 0.20 & 0.20 & 0.20 & 0.20 & 0.20 \\
Lysine & 0.25 & 0.25 & 0.25 & 0.25 & 0.25 \\
Syzygiumaromaticum & - & - & 1.00 & - & - \\
Piper nigrum & - & - & - & 1.00 & - \\
Tetrapleuratetreptera & - & - & - & - & 1.00 \\
\hline Total & 100 & 100 & 100 & 100 & 100 \\
Determined analysis $(\boldsymbol{\%})$ & & & & & \\
Crude protein & 22.43 & 22.43 & 22.43 & 22.43 & 22.43 \\
Crude fibre & 2.05 & 2.05 & 2.55 & 2.56 & 2.76 \\
Ether extract & 3.85 & 3.85 & 4.05 & 4.09 & 4.24 \\
Ash & 3.47 & 3.78 & 4.11 & 4.17 & 3.25 \\
\hline
\end{tabular}

*Starter premix: - Vit. A 10,000,000 (iu), Vit D3 2,000,000 (iu),Vit. E 23,000(mg), Vit K 3(mg), Vit B1 1,800 (mg), Vit. B2 5,500 (mg), Niacin 27,500 mg, Pantothenic acid 7,500mg, Vit. B6 3,000mg, Vit.B12 15mg, Folic acid 750mg, Biotin H2 60mg, Chlorine chloride 300,000mg, Cobalt 200mg, Copper 3,000mg, Iodine 1,000 mg, Iron 20,000mg, Manganese 40,000(mg), Selenium 200mg, Zinc 30,000mg, Anti-oxidant 1,250mg.T1 - without antioxidants T2 - with synthetic antioxidants.T3 - with Syzygium aromaticum (Cloves), T4 - with Piper nigrum (Black pepper),T5 - with Tetrapleuratetraptera (Prekese).

Table 2: Ingredients and chemical composition of basal diet for finisher (29-56 D) broiler.

\begin{tabular}{|llllll|}
\hline Ingredients & T1 & T2 & T3 & T4 & T5 \\
\hline Maize & 58.00 & 58.00 & 58.00 & 58.00 & 58.00 \\
Soya bean meal & 25.00 & 25.00 & 25.00 & 25.00 & 25.00 \\
Vegetable oil & 2.00 & 2.00 & 2.00 & 2.00 & 2.00 \\
Wheat offal & 7.00 & 7.00 & 6.00 & 6.00 & 6.00 \\
Fishmeal & 2.00 & 2.00 & 2.00 & 2.00 & 2.00 \\
Bone meal & 2.00 & 2.00 & 2.00 & 2.00 & 2.00 \\
Limestone & 3.00 & 3.00 & 3.00 & 3.00 & 3.00 \\
Salt & 0.30 & 0.30 & 0.30 & 0.30 & 0.30 \\
\hline
\end{tabular}


Vol. 5, No. 03; 2020

ISSN: $2456-8643$

\begin{tabular}{|llllll|}
\hline *Premix & 0.30 & 0.30 & 0.30 & 0.30 & 0.30 \\
Methionine & 0.20 & 0.20 & 0.20 & 0.20 & 0.20 \\
Lysine & 0.20 & 0.20 & 0.20 & 0.20 & 0.20 \\
Syzygiumaromaticum & - & - & 1.00 & - & - \\
Piper nigrum & - & - & - & 1.00 & - \\
Tetrapleuratetreptera & - & - & - & - & 1.00 \\
\hline Total & 100 & 100 & 100 & 100 & 100 \\
Determined analysis $(\%)$ & & & & & \\
Crude protein & 20.33 & 20.33 & 20.33 & 20.33 & 20.33 \\
Crude fibre & 4.08 & 4.08 & 4.08 & 4.07 & 4.10 \\
Ether extract & 3.91 & 3.62 & 3.57 & 3.52 & 4.36 \\
Ash & 3.04 & 2.97 & 2.91 & 2.85 & 2.75 \\
\hline
\end{tabular}

Starter premix: - Vit. A 10,000,000 (iu), Vit D3 2,000,000 (iu),Vit. E 23,000(mg), VitK3(mg), Vit B1 1,800 (mg), Vit. B2 5,500 (mg), Niacin 27,500 mg, Pantothenic acid 7,500mg, Vit. B6 3,000mg, Vit.B12 15mg, Folic acid 750mg, Biotin H2 60mg, Chlorine chloride 300,000mg, Cobalt 200mg, Copper 3,000mg, Iodine 1,000mg, Iron 20,000mg, Manganese 40,000(mg), Selenium 200mg, Zinc 30,000mg, Anti-oxidant 1,250mg.T1 - without antioxidants T2 - with synthetic antioxidants.T3 - with Syzygium aromaticum (Cloves),T4 - with Piper nigrum (Black pepper),T5 - with Tetrapleuratetraptera (Prekese).

\section{DATA COLLECTION}

Measurement of blood profile

Hematological Indices: At $56^{\text {th }}$ day blood samples were collected from 10 birds per treatment through wing vein using sterilized syringe into vials containing anticoagulant to determine the following: packed cell volume (PCV), red blood cell count (RBC), hemoglobin concentration $(\mathrm{Hb})$, white blood cell count (WBC) and differential counts using standard techniques (Schalms et al., 1975; Coles, 1986).

\section{Serum metabolites:}

Blood samples were collected from 10 birds per treatment through wing vein using sterilized syringe into vials without anticoagulants and allowed to clot. The serum from the clotted blood samples were used to determine Total serum protein (TSP), Serum albumin (SA), Serum globulin (SG), Serum uric acid (SUA), Serum creatinine (SC), Serum glucose (SG), Serum enzyme activity (ALT and AST) were determined according to the method of Colowick and Kaplan (1955). Serum cholesterol was determined as described by Roeschlau et al. (1974).

Caeca microflora: Caecal contents were collected aseptically into sample bottles and stored in a refrigerator $\left(-20^{\circ} \mathrm{C}\right)$ for microbiological analysis. Estimation of total bacteria counts, Coliform, Clostridium, Lactobacillus, Bacillus, Salmonella, Staphylococcus counts were done according to the method of Baker and Beach (1998)

Gut Morphometric: About $2 \mathrm{~cm}$ of different segments (duodenum, ileum and jejunum) of the intestinal samples were collected and fixed in $10 \%$ formalin for one week. The specimens were dehydrated in graded levels of alcohol (70\%-100\%) to remove the water content. After the 
dehydration, the specimens were cleared in xylene, impregnated with paraffin wax blocked and sectioned at 5 microns thickness using Rotary Microtome (Leica). The sections were floated on a paraffin water bath maintained at a temperature of $2-3{ }^{\circ} \mathrm{c}$ below melting point of the paraffin wax after which the sections were dried on a slide dryer. After proper drying the section were stained with Haematoxylin and Eosin (H\&E) and using Histomount. The slide were place on the stage of the Microscope, with aid of the Eye piece graticules on the microscope the average measurement of following area were taken villus height (VH) Apical width (AW) Basal width(BW)and Lamina propria depth(LPD) for each sample for further analysis.

Statistical analysis: Data obtained was analyzed using SAS statistical software SAS ${ }^{\circledR}$ version 2000. Different between significant means were separated using Turkey's Test. While Statements of significance was based on a probability of $\mathrm{P}<0.05$.

\section{RESULTS AND DISCUSSION}

\section{Effect of antioxidants addition on hematological parameters of broiler finisher}

Table 3 shows the hematological parameters of broiler chicken fed Syzygium aromaticum, Piper nigrum, Tetrapleura tetraptera. The inclusion of the phytogenic plants had a significant $(\mathrm{P}<0.005)$ effect on the values recorded. The values of packed cell volume, haemoglobin and red blood cells as well as heterophils, lymphocytes and monocytes and basophil values were significantly $(\mathrm{P}<0.005)$ affected. Haematological values could serve as baseline information for comparison in conditions of nutrient deficiency, physiology and health status of farm animals (Daramola et al., 2005). The results PCV, RBC, WBC, Hb, heterophils, lymphocytes, monocytes and basophils were significantly different, however eosinophil values were not significant. There is an increase in the value (37\%) of PCV in birds fed synthetic antioxidants, while lowest value (31\%) was recorded in birds on T1 (no synthetic, no natural antioxidants). The observed PCV values indicated that broiler chickens on T3, T4 and T5 were not anaemic, this result corroborated with Chineke et al. (2006) findings that PCV value denotes an increase in the number of RBCs or reduction in circulatory plasma volume. The haemoglobin values recorded have a direct link with the nutritional status of the broiler chickens as the present values were in order with Bamidele and Adejumo,(2012) findings, however, increase in the values recorded in this study was due constituents in the phytogenic spices. The white blood cell values of broiler chickens on phytogenic herbs recorded the lowest Monocyte counts except for the diet with the inclusion of Piper nigrum. Monocytes are the largest member of white blood cells and are capable of travelling to various parts of the body to eliminate harmful matter. This may signify that the increase in white blood cell count in the phytogenic diet was not as a result of inflammation or disease which ordinarily should have increased the monocyte count but the antioxidative properties of the phytogenic plants was less responsible in maintaining total white blood count. Heterophil activity were highest in Syzygium aromaticum and Tetrapleura tetraptera. The difference in WBC values implies varied intrinsic body defence system (Ganomg, 1991) as indicated by the higher lymphocyte counts in broiler chickens on phytogenic spices. This implies that the immune system of the birds were not compromised with the feeding trials. The WBC differentials (monocytes, eosinophils, basophiles and heterocytes) are within the normal range for healthy birds (Mitruka and Rawsley, 1977; Archetti et al., 2008). 
Vol. 5, No. 03; 2020

ISSN: $2456-8643$

Table 3: Effect of antioxidants on hematological parameters of broiler finisher

\begin{tabular}{|llllllll|}
\hline Parameters & T1 & T2 & T3 & T4 & T5 & SEM & P-value \\
\hline Packed Cell Volume (\%) & $31.00^{\mathrm{c}}$ & $37.00^{\mathrm{a}}$ & $32.67^{\mathrm{b}}$ & $33.00^{\mathrm{b}}$ & $32.67^{\mathrm{b}}$ & 0.56 & $<.0001$ \\
Haemoglobin(g/dl) & $10.50^{\mathrm{d}}$ & $11.70^{\mathrm{a}}$ & $11.00^{\mathrm{c}}$ & $11.40^{\mathrm{b}}$ & $10.97^{\mathrm{c}}$ & 0.11 & $<.0001$ \\
Red Blood Cell (x1012/1) & $2.40^{\mathrm{d}}$ & $3.04^{\mathrm{a}}$ & $2.66^{\mathrm{bc}}$ & $2.72^{\mathrm{b}}$ & $2.65^{\mathrm{c}}$ & 0.55 & $<.0001$ \\
White Blood Cell (Cumm $^{3}$ ) & 12.33 & 13.90 & 13.68 & 11.68 & 12.90 & 0.33 & 0.17 \\
Heterophils (\%) & $36.00^{\mathrm{a}}$ & $30.33^{\mathrm{b}}$ & $30.33^{\mathrm{b}}$ & $38.67^{\mathrm{a}}$ & $38.67^{\mathrm{a}}$ & 1.06 & $<.0001$ \\
Lymphocytes (\%) & $60.00^{\mathrm{b}}$ & $65.00^{\mathrm{a}}$ & $65.33^{\mathrm{a}}$ & $67.33^{\mathrm{b}}$ & $67.33^{\mathrm{a}}$ & 1.13 & 0.003 \\
Eosinophils (\%) & 2.67 & 2.67 & 4.00 & 3.00 & 3.00 & 0.21 & 0.23 \\
Monocytes (\%) & $1.00^{\mathrm{b}}$ & $1.00^{\mathrm{b}}$ & $1.00^{\mathrm{b}}$ & $1.67^{\mathrm{a}}$ & $1.00^{\mathrm{b}}$ & 0.09 & 0.03 \\
Basophils (\%) & 0 & 0 & 0 & 0 & 0 & 0 & 0 \\
\hline
\end{tabular}

$\mathrm{a}, \mathrm{b}, \mathrm{c}, \mathrm{d}$ Means in a row having different superscripts are significantly different $(\mathrm{p}<0.05)$

SEM- Standard error of mean, T1 - without antioxidant, T2 - with antioxidant, T3 - with Syzygium aromaticum, T4- with Piper nigrum, T5 - with Tetrepleuratetraptera.

\section{Effect of antioxidants addition on serum parameters of broiler finisher}

Table 4 showed the serum indices of broiler chickens fed with Syzygiumaromaticum, Piper nigrum, Tetrapleuratetrapteraas antioxidants. It can be observed that birds on synthetic antioxidants had highest blood protein value $(15.37 \mathrm{~g} / \mathrm{l})$ as against the valiues $(9.17-9.50 \mathrm{~g} / \mathrm{l})$ recorded in birds fed phytogenic plants. Uric acid, creatinine, globulin, triglycerol, cholesterol values as well as alanine transferase and aspartate transferase reduced significantly with inclusion of phytogenic plants in the diets. The serum biochemical values reflect effect of dietary treatments as studies (Iyayi and Tewe, 1998; Esonu et al., 2001) confirmed that serum protein and creatinine values are reflection of quantity and quality of dietary protein fed. The cholesterol values in this study reduced in broiler chickens on phytogenic spices which are comparable to previous studies (Imaseun and Ijeh, 2017) which is consistent with the wellobserved effect of pepper on lowering blood cholesterol level and thus prevent absorption of cholesterol as reported in Aghil et al., (2013). This is very much important as transfer of cholesterol to human body via the animal consumption. Creatinine values ranging from $1.7-$ $2.5 \mathrm{mg} / \mathrm{dl}$ are normal, it has been stated that inclusion of the spices reduced the creatinine values translating to improve protein utilization as it was also confirmed by the uric acid values (0.81$1.74 \mathrm{mg} / \mathrm{dl}$ ) values which decreases with inclusion of phytogenic spices. Liver enzymes activities of Alanine aminotransferase (ALT) and Aspartate aminotransferase (AST) in the serum of broiler chicken fed different antioxidants source were similar among the dietary treatments except the control having a higher value, however, values ranged within the normal values reported by Mitruka and Rawnsley (1977), implied no impairment on heart and liver in broilers fed with phytogenic spices. 
Table 4: Effect of Antioxidants on serum indices of broiler finisher.

\begin{tabular}{|llllllll|}
\hline Parameters & T1 & T2 & T3 & T4 & T5 & SEM & P-value \\
\hline Total Protein (g/l) & $10.77^{\mathrm{b}}$ & $15.37^{\mathrm{a}}$ & $9.17^{\mathrm{d}}$ & $9.40^{\mathrm{c}}$ & $9.50^{\mathrm{c}}$ & 0.62 & $<.0001$ \\
Globulin(g/l) & $6.67^{\mathrm{b}}$ & $10.07^{\mathrm{a}}$ & $5.17^{\mathrm{d}}$ & $5.57^{\mathrm{c}}$ & $4.47^{\mathrm{c}}$ & 0.53 & $<.0001$ \\
Albumin(g/l) & $4.10^{\mathrm{b}}$ & $5.37^{\mathrm{a}}$ & $4.00^{\mathrm{b}}$ & $3.87^{\mathrm{b}}$ & $4.13^{\mathrm{b}}$ & 0.15 & $<.0001$ \\
Uric acid(mg/dl) & $1.07^{\mathrm{b}}$ & $1.74^{\mathrm{a}}$ & $1.02^{\mathrm{C}}$ & $0.81^{\mathrm{e}}$ & $1.00^{\mathrm{d}}$ & 0.09 & $<.0001$ \\
Creatinine(mg/dl) & $2.37^{\mathrm{a}}$ & $2.50^{\mathrm{a}}$ & $1.70^{\mathrm{b}}$ & $1.87^{\mathrm{b}}$ & $1.90^{\mathrm{b}}$ & 0.09 & $<.0001$ \\
Glucose (mg/dl) & $114.70^{\mathrm{a}}$ & $101.40^{\mathrm{b}}$ & $95.10^{\mathrm{c}}$ & $90.13^{\mathrm{d}}$ & $79.33^{\mathrm{e}}$ & 3.13 & $<.0001$ \\
Triglycerol(mg/dl) & $57.80^{\mathrm{b}}$ & $60.33^{\mathrm{a}}$ & $54.43^{\mathrm{c}}$ & $51.07^{\mathrm{d}}$ & $50.70^{\mathrm{e}}$ & 1.00 & $<.0001$ \\
Cholesterol (g/l) & $163.70^{\mathrm{b}}$ & $174.33^{\mathrm{a}}$ & $154.40^{\mathrm{c}}$ & $130.77^{\mathrm{e}}$ & $132.50^{\mathrm{d}}$ & 4.58 & $<.0001$ \\
Alanine transferase (iu/l) & $216.77^{\mathrm{a}}$ & $193.17^{\mathrm{b}}$ & $159.67^{\mathrm{e}}$ & $162.80^{\mathrm{d}}$ & $172.40^{\mathrm{c}}$ & 5.72 & $<.0001$ \\
Aspartate transferase (iu/l) & $203.77^{\mathrm{a}}$ & $192.80^{\mathrm{b}}$ & $169.80^{\mathrm{e}}$ & $171.20^{\mathrm{d}}$ & $186.67^{\mathrm{c}}$ & 3.46 & $<.0001$ \\
\hline
\end{tabular}

$\mathrm{a}, \mathrm{b}, \mathrm{c}, \mathrm{d}$ Means in a row having different superscripts are significantly different $(\mathrm{p}<0.05)$

SEM- Standard error of mean, T1 - without antioxidant, T2 - with antioxidant

T3 - with Syzygium aromaticum, T4- with Piper nigrum, T5 - with Tetrepleura tetraptera.

\section{Effect of antioxidants addition on micro-flora parameters of broiler finisher}

The response to treatments via gut micro biota is shown in Table 5. It could be observed that total bacteria counts were significantly $(\mathrm{P}<0.005)$ affected by the dietary treatments. The result showed that birds on T4 had highest Lactobacillus and bacillus population while clostridium, staphylococcus and salmonella counts were lowered. The observed results could be due to effect of active ingredients in the spices used in this experiment. Studies (Manzanillo et al., 2001; Agostini et al., (2012) revealed that diets supplemented with carvacrol, cinnamaldehyde and capsaicin stimulates Lactobacillus growth and reduction in the proliferation of pathogenic bacteria in monogastric animals. Similar trend was observed in the gut microflora counts in the present study in diets supplemented with $P$. nigrum and $T$. tetraptera when compared with the gut micro biota of broiler on control diet.

Table 5: Effect of antioxidants on micro-flora parameters of broiler finisher

\begin{tabular}{|c|c|c|c|c|c|c|c|}
\hline Parameters & T1 & $\mathbf{T 2}$ & T3 & T4 & T5 & SEM & P-value \\
\hline $\begin{array}{l}\text { Total bacteria } \\
\left(\times 10^{6} \mathrm{cfu} / \mathrm{ml}\right)\end{array}$ & $2.60^{\mathrm{a}}$ & $2.60^{\mathrm{a}}$ & $1.77^{\mathrm{b}}$ & $2.60^{\mathrm{a}}$ & $1.80^{\mathrm{b}}$ & 0.10 & $<.0001$ \\
\hline Lactobacillus $\left(\times 10^{6} \mathrm{cfu} / \mathrm{ml}\right)$ & $0.77^{\mathrm{c}}$ & $1.00^{\mathrm{b}}$ & $0.30^{\mathrm{e}}$ & $1.27^{\mathrm{a}}$ & $0.50^{\mathrm{d}}$ & 0.09 & $<.0001$ \\
\hline Staphylococcus $\left(\times 10^{6} \mathrm{cfu} / \mathrm{ml}\right)$ & $0.47^{\mathrm{ab}}$ & $0.40^{\mathrm{b}}$ & $0.47^{\mathrm{ab}}$ & $0.50^{\mathrm{ab}}$ & $0.67^{\mathrm{a}}$ & 0.03 & 0.11 \\
\hline Salmonella $\left(x 10^{6} \mathrm{cfu} / \mathrm{ml}\right)$ & $0.20^{\mathrm{d}}$ & $0.50^{\mathrm{c}}$ & $0.60^{\mathrm{bc}}$ & $0.70^{\mathrm{b}}$ & $0.90^{\mathrm{a}}$ & 0.7 & $<.0001$ \\
\hline Coliform $\left(\times 10^{6} \mathrm{cfu} / \mathrm{ml}\right)$ & $0.20^{\mathrm{d}}$ & $1.80^{\mathrm{a}}$ & $0.60^{\mathrm{c}}$ & $1.00^{\mathrm{b}}$ & $0.27^{\mathrm{d}}$ & 0.19 & $<.0001$ \\
\hline Bacillus $\left(\times 10^{6} \mathrm{cfu} / \mathrm{ml}\right)$ & $1.30^{\mathrm{a}}$ & $1.00^{\mathrm{b}}$ & $0.40^{\mathrm{c}}$ & $1.00^{\mathrm{b}}$ & $0.30^{\mathrm{c}}$ & 0.10 & 0.003 \\
\hline Clostridium $\left(\mathrm{x} 10^{6} \mathrm{cfu} / \mathrm{ml}\right)$ & $0.80^{\mathrm{a}}$ & $0.70_{\mathrm{ab}}$ & $0.60^{\mathrm{bc}}$ & $0.30^{\mathrm{d}}$ & $0.50^{\mathrm{c}}$ & 0.05 & $<.0001$ \\
\hline
\end{tabular}

$\mathrm{a}, \mathrm{b}, \mathrm{c}, \mathrm{d}$ Means in a row having different superscripts are significantly different $(\mathrm{p}<0.05)$

SEM- Standard error of mean, T1 - without antioxidant, T2 - with antioxidant, T3 - with Syzygium aromaticum, T4- with Piper nigrum, T5 - with Tetrepleura tetraptera 


\section{Effect of antioxidants addition on morphometric parameters of broiler finishers}

Changes in intestinal morphometric following inclusion of different antioxidant sources could be observed in Table 6. The result showed that the duodenal villus height, crypt depth as well as lamina propria of the broiler chickens were significantly $(\mathrm{P}<0.005)$ affected by the dietary treatments. The dietary treatments had significant $(\mathrm{P}<0.05)$ effect on the ileum villus height, crypt depth as well as lamina propria of the broiler chickens. While the villus height, crypt depth and lamina propria across the treatments were affected. This could be due to the antioxidative constituents in phytogenic spices used in this study. Similar studies (Adusei et al., 2019; Khathir et al. 2014; Nakatani, 1994) confirmed antioxidant activities in T. tetraptera, S. aromaticum and P.nigrum with high lipid inhibition. Observed changes in the intestinal segments is more pronounced in the jejunum meaning the segment is vital to fat, starch, and protein absorption.

Thus increased jejuna villi height in broilers fed diet supplemented with $T$. tetraptera translated to better surface area for nutrients absorption. This observation complied with (Maneewan and Yamauchi, 2004; De Los Santos et al., 2007) that intestinal villi has direct link with growth performance; longer villi height are associated with increased body weight gain. Reduction in jejuna crypt depth in broilers fed with $T$. tetraptera is indicative of improved intestinal health as shallower crypts means improved performance (Markovi et al., 2009). As shown in the result, the $(20 \mu \mathrm{m})$ villi height/crypt depth ratio indicated better digestive capacity in small intestine as villus height/crypt depth ratio is a useful criterion for estimating the digestive capacity Montagne et al. (2003). Observed trend agreed the previous study Montagne et al. (2003) that inclusion of Phytogenic spices as additives improved intestinal morphology in broiler chickens. However, results obtained in this study is constituents dependent as optimal response is obtained in diet supplemented with $T$. tetraptera.

Table 6: Effect of antioxidants on gut morphometric parameters of broiler finishers

\begin{tabular}{|llllllll|}
\hline Parameters $(\mu \mathrm{m})$ & $\mathrm{T} 1$ & $\mathrm{~T} 2$ & $\mathrm{~T} 3$ & $\mathrm{~T} 4$ & $\mathrm{~T} 5$ & SEM & P.value \\
\hline Duodenum & & & & & & & \\
Villus height & $1200.00^{\mathrm{c}}$ & $1300.00^{\mathrm{b}}$ & $1233.33^{\mathrm{c}}$ & $1200.00^{\mathrm{c}}$ & $1476.67^{\mathrm{a}}$ & 28.74 & $<.0001$ \\
Crypt depth & $49.33^{\mathrm{c}}$ & $50.00^{\mathrm{c}}$ & $52.67^{\mathrm{b}}$ & $53.33^{\mathrm{b}}$ & $70.00^{\mathrm{a}}$ & 2.36 & 0.00 \\
Lamina Propria & $200.00^{\mathrm{c}}$ & $230.00^{\mathrm{ab}}$ & $210.00^{\mathrm{bc}}$ & $240.00^{\mathrm{a}}$ & $250.00^{\mathrm{a}}$ & 5.61 & 0.0025 \\
Ileum & & & & & & & \\
Villus height & $700.00^{\mathrm{d}}$ & $1000.00^{\mathrm{b}}$ & $800.00^{\mathrm{c}}$ & $1250.00^{\mathrm{a}}$ & $1000.00^{\mathrm{b}}$ & 51.29 & $<.0001$ \\
Crypt depth & $60.00^{\mathrm{c}}$ & $78.33^{\mathrm{ab}}$ & $80.00^{\mathrm{a}}$ & $40.00^{\mathrm{d}}$ & $40.00^{\mathrm{d}}$ & 0.90 & 0.002 \\
Lamina Propria & $240.00^{\mathrm{b}}$ & $120.00^{\mathrm{c}}$ & $300.00^{\mathrm{a}}$ & $250.00^{\mathrm{b}}$ & $260.00^{\mathrm{b}}$ & 16.76 & $<.0001$ \\
Jejunum & & & & & & & \\
Villus height & $950.00^{\mathrm{a}}$ & $400.00^{\mathrm{b}}$ & $603.30^{\mathrm{ab}}$ & $700.00^{\mathrm{ab}}$ & $1000.00^{\mathrm{a}}$ & 78.61 & 0.05 \\
Crypt depth & $60.00^{\mathrm{b}}$ & $90.00^{\mathrm{a}}$ & $50.00^{\mathrm{c}}$ & $50.00^{\mathrm{c}}$ & $50.00^{\mathrm{c}}$ & 0.44 & 0.002 \\
Lamina Propria & $150.00^{\mathrm{c}}$ & $200.00^{\mathrm{b}}$ & $300.00^{\mathrm{a}}$ & $200.00^{\mathrm{b}}$ & $200.00^{\mathrm{b}}$ & 13.73 & $<.0001$ \\
\hline
\end{tabular}

a,b,c,d Means in a row having different superscripts are significantly different $(\mathrm{p}<0.05)$

SEM- Standard error of mean, T1 - without antioxidant, T2 - with antioxidant, T3 - with Syzygium aromaticum, T4- with Piper nigrum, T5 - with Tetrepleura tetraptera. 
Vol. 5, No. 03; 2020

ISSN: $2456-8643$

\section{CONCLUSION}

It can be concluded that these phytogenic antioxidants are able to replace the synthetic antioxidants ( $\alpha$-tocopherol) in feeding practice. However, the three phytogenic spices had effects on parameters measured. Therefore, decision should be made based the results of the intestine morphometric, blood profile and caecal microbial population in broilers with optimal response with T. tetraptera.

Conflicts of Interest: The authors have declared no conflict of interest for this article

\section{REFERENCES}

Adebayo, A. S., I. A. Gbadomosi, and C. O. Adewunmi. (2000) Formulation of antimicrobial dried powdered herbs in soap basis. In C. O. Adewunmi and S. K. Adesina, eds. Phyto Medicines in Malaria and Sexually Transmitted Disease, Challenges for the New Millennium. Obafemi Awolowo University, Ile-Ife. 97.

Agostini, P.S., Solà-Oriol, D., Nofrarías, M., Barroeta, A.C., Gasa, J and Manzanilla, E.G., (2012). Role of in-feed clove supplementation on growth performance, intestinal microbiology, and morphology in broiler chicken. Livestock Science.147, 113-118.

Archetti I, Tittarelli C, Ceriolo M, Brivio R, Grilli G ad Lavazza A. (2008). Serum chemistry and hematology values in commercial rabbits: preliminary data from industrial farms in Northern Italy. Proceedings of 9th the World Rabbit Congress, Italy. Pp. 1147-1151.

Adejumo D. O. (2004). Performance, organ development and haematological of rats fed sole diets of graded levels of cassava flour and soybean flour (Soygari) as substitutes for energy and protein concentrates. Tropical Journal of Animal Science. 7:57-63.

Aghil, S, Farshid, K, Mostafa, F, Yaser, R and Ali, R. (2013). The effect of use red pepper (Capsicum annum L) and black pepper (Piper nigrum L) on performance and hematological parameters of broiler chicks. European Journal of Zoological Research, 2013, 2 (6):44-48

Baker, F.J and Beach, M.R. (1993).Total and value count technique. Medical microbiology Techniques. 5th Edition Oxford publisher pp 418-422.

Bamidele, O and Adejumo, I.O (2012). Effect of garlic (Allium sativa L.) and ginger (Zingiber officinale Roscoe) mixtures on performance characteristics and cholesterol profile of growing pullets. International Journal of Poultry Science. 11(3): 217- 220.

Botsoglou, E, Govaris, A, Fletouris, D and Iliadis, S. (2013). Olive leaves (Olea europea L.) and $\alpha$-tocopheryl acetate as feed antioxidants for improving the oxidative stability of $\alpha$ linolenic acid-enriched eggs. Journal of Animal Physiology, Animal Nutrition. 97: 740753.

Colowick, S.P and Kaplan, N..O (1955). Method of enzymology. 2nd edition. New York Academic press, New York. 1:10.

Coles, E. H. (1974). Veterinary clinical pathology. 4th ed. E. H. Coles, W. B.Saunders Company, Philadelphia, USA.

Chaieb, K, Zmantar, T, Ksouri, R, Hajlaoui, H, Mahdouani, K, Abdelly, C and Bakhrouf, A (2007b). Antioxidant properties of essential oil of Eugenia caryophyllata and its 
Vol. 5, No. 03; 2020

ISSN: $2456-8643$

antifungal activity against a large number of clinical Candida species. Journal of Mycosis. 50(5):403-6.

Chineke, C.A., Ologun A.G and Ikeobi C.O. (2006). Haematological parameters in rabbit breeds and crosses in humidtropics. Pakistan Journal of Biological Science. 9:2102-2106.

Daramola, J.O, Adeloye, A.A, Fatoba, T.A and Soladoye, A.O (2005). Hematological and biochemical parameters of West African Dwarf goats. Livestock Research for Rural Development. 17(8): 95.

De Los Santos, F.S, Donoghue, A.M, Farnell, M.B, Huff, G.R, Huff, W.E and Donoghue D.J (2007).Gastrointestinal maturation in turkey poults supplemented with a mannanoligosaccharide yeast extract (Alphamune). Poultry Science, 86, 921-930.

Esonu, B.O., Emenalom, O.O., Udedibie, A.B.I., Herbert, U., Ekpor, C.F., Okoli, I.C and Iheukwumere F.C (2001). Performance and blood chemistry of weaner pigs fed raw mucuna beans (velvet bean) meal. Tropical Animal Production Investigation. 4:49-54.

Ganomg, J.E. (1991). A review of medical physiology. Lange Medical Publication. 115p.

Google Earth, 2019. http/ www. Google, earth.

Iyayi, E.A and Tewe, O.O (1998). Serum total protein urea and creatinine levels as indices of quality of cassava diet for pigs. Tropical Veterinary.36:59-67

Imaseun, J.A and Ijeh, O.A (2017). Hematological parameters, serum biochemistry and antioxidant capacity of broiler chickens fed diet supplemented with two sources of antioxidants as feed additives. Journal of Agriculture and Veterinary Science. 10:9. 23192372.

Maneewan, B and Yamauchi, K. (2004). Intestinal villus recovery in chickens fed semi-purified protein, fat, or fiber-free pellet diets. British Poultry Science. 45:163-170.

Manzanilla, E.G, Perez, J.F, Martin, M, kamel, C, Baucells, F and Gasa, J. (2004). Effect of plant extracts and formic acid on the intestinal equilibrium of early weaned pigs, Journal of Animal Science.82:3210-8.

Mittal, M., Gupta, N., Parashar, P, Mehra, V and Khatri, M (2014). Phytochemical evaluation and pharmacological activity of Syzygium aromaticum: A comprehensive review. International Journal of Pharmacy and Pharmaceutical Sciences. 6. 8

Mitruika, B.T and Rawnsley, H (1977). Clinical biochemical and hematology value in normal Animals. Mason Publishing, New York, USA. Pp 171-174.

Montagne, L, Pluske, J.R and Hampson, D.J (2003). A review of interactions between dietary fiber and the intestinal mucosa, and their consequences on digestive health in young nonruminant animals. Anim. Feed Science and Technology. 108: 95-117.

Markovic, R, Sefer, D, Krstic, M, Petrujkic, B.(2009).The effect of different growth promotors on broiler performance and gut morphology. Archivos de MedicinaVeterinaria. 41:163169.

Nakatani, N. (1994). Antioxidants from spices and herbs. In Food Phytochemicals for Cancer Prevention II: Teas, Spices and Herbs. ACS Symposium Series 547. C.-T. Ho, T. Osawa, M.-T.Huang, and R. T. Rosen, ed. American Chemical Society, Washington, DC.

NRC. (1994).National Research Council, Nutrient Requirements of Poultry 9th Ed. National Academy Press. Washington, DC. 
Nwoba E.G. (2015). Proximate and phytochemical composition of the pulp of Tetrapleura tetraptera fruits consumed in Abakaliki, Nigeria. International Journal of Engineering Research and Technology. 4: 6

SAS Institute. 2000. SAS/STAT(R) Inc. User's Guide, Version 9, SAS Institute, Inc. Cary, NC.

Sashidhar, N.S. (2000). Studies on bioactive natural compounds for their antimicrobial and antioxidant properties. Ph.DThesis2002,OsmaniaUniversity Hyderabad India.

Schalm, O.W., Jain, N.C. and Carol, E. 1975. Veterinary hematology 3rd Lea and Feb i g e r, Philadelphia, USA.160-210.

Zheng, G.Q, Kenny, P.M and Lam, K.T. (1992).Sesquiterpenes from clove (Eugenia carrophyllata) as potential anticarcinogenic agents. Journal of Natural Products. 55:9991003. 